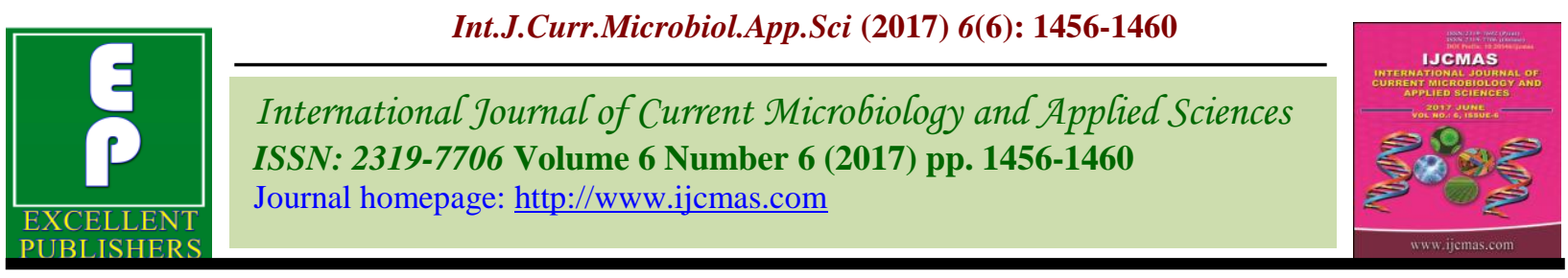

Original Research Article

https://doi.org/10.20546/ijcmas.2017.606.170

\title{
Effect of Different Levels of Nitrogen on Growth and Yield in Potato (Solanum tuberosum L.) CV. Kufri Khyati
}

\author{
Sriom $^{1^{*}}$, D.P. Mishra ${ }^{2}$, Priyanka Rajbhar ${ }^{3}$, Devraj Singh ${ }^{4}$, \\ Rajat Kumar Singh ${ }^{5}$ and Sudhir Kumar Mishra ${ }^{6}$
}

\author{
${ }^{1}$ Department of Vegetable Science, NDUA\&T Kumarganj Faizabad-224229, India \\ ${ }^{2}$ Department of Vegetable Science, SHUATS, Naini, Allahabad, India \\ *Corresponding author
}

\begin{abstract}
Keywords
Growth attributes,

Potato,

Yield and nitrogen levels.

Article Info

Accepted:

21 May 2017

Available Online:

10 June 2017
\end{abstract}

\section{A B S T R A C T}

The present investigation was carried out at Main Experiment Station, Department of Vegetable Science, Narendra Deva University of Agriculture and Technology, Kumarganj, Faizabad (U.P.), during the year 2014-15 and 2015-16. The seven treatments were evaluated on the CV. Kufri Khyati in Randomized Block Design with three replications. The study revealed that almost growth characters are influenced and found significantly higher by the increasing of the levels of nitrogen. The growth characters viz., Plant height, number of haulms per hill, number of leaves per plant, fresh weight and dry weight of plant recorded maximum with the application of treatment $\left(\mathrm{T}_{5}\right) 200 \mathrm{~kg} \mathrm{~N} /$ ha during both the years (2014-15 and 2015-16). The study further revealed that the treatment $\mathrm{T}_{5}$ also had obtained maximum per plot yield and yield per hectare during both the years of investigation.

\section{Introduction}

Potato (Solanum tuberosum L.) is wholesome food and belongs to the family Solanaceae. It has originated in South America and now commercially grown in all over the world. In India, it has been introduced in the early 17 th century by Portuguese traders and gradually become a commercial crop of all over India. Potato is grown in almost all states of India. The leading states in terms of area, production and productivity are Gujarat, Uttar Pradesh, Bihar, West Bengal and Punjab. The other major potato growing states are Assam, M.P., Haryana, Meghalaya, Karnataka, Tamil Nadu,
Himachal Pradesh and Maharashtra. Potato is a relatively stable part of the diet of European and North American people. Potato contains practically all essential dietary constituents like carbohydrates, essential nutrients, protein, vitamins and minerals. Normally some potato tubers of Indian cultivars contain less than $20 \mathrm{mg}$ glycoalkaloids per $100 \mathrm{~g}$ fresh weight and cause no harmful effects. Nitrogen is the most limiting factor in Indian soils. It is known that about $4000 \mathrm{Mt}$ of nitrogen is presented in an atmosphere which about seventy seven thousand tonnes over an 
area of one hectare land. In fact, this vast reserve of nitrogen could remain utilizable by the crops until it converted into available from either through industrial synthesis or through bio-fixation.

\section{Materials and Methods}

The experiment was conducted during the winter season of 2014-15 and 2015-2016 at Main Experiment Station Department of Vegetable Science, Narendra Deva University of Agriculture and Technology, Narendra Nagar (Kumarganj), Faizabad (U.P.). Faizabad region receives a mean annual precipitation of about $1200 \mathrm{~mm}$.

Maximum rainfall in this area is received from mid-June to end of September. However, occasional showers are very common in the month of January and February.

The experiment was conducted in Randomized Block Design (RBD) with four replications. The seven treatments were allocated randomly into the plots in such a way that each and every treatment was received only once in each block.

\section{Details of treatments}

\section{Nitrogen levels: 7}

$\begin{array}{lll}\mathrm{T}_{1} & : & 0 \mathrm{~kg} \mathrm{~N} / \mathrm{ha} \\ \mathrm{T}_{2} & : & 50 \mathrm{~kg} \mathrm{~N} / \mathrm{ha} \\ \mathrm{T}_{3} & : & 100 \mathrm{~kg} \mathrm{~N} / \mathrm{ha} \\ \mathrm{T}_{4} & : & 150 \mathrm{~kg} \mathrm{~N} / \mathrm{ha} \\ \mathrm{T}_{5} & : & 200 \mathrm{~kg} \mathrm{~N} / \mathrm{ha} \\ \mathrm{T}_{6} & : & 250 \mathrm{~kg} \mathrm{~N} / \mathrm{ha} \\ \mathrm{T}_{7} & : & 300 \mathrm{~kg} \mathrm{~N} / \mathrm{ha}\end{array}$

\section{Results and Discussion}

The emergence per cent at (Table 1) 30 days after planting did not influence significantly due to various treatments. As another factor such as tuber size and post-cold storage period, influencing emergence were common to all treatments.

It may be due to the food material already stored in the seed tubers, which gave an initial boost to the emerging plants. Satyanarayan (1983) and Dandekar et al., (1991) had also not observed any significant effect of increasing levels of nitrogen on plant emergence.

Nitrogen being an essential constituent of protoplasm is vitally associated with the activity of every living cell. In the present investigation nitrogen application has a profound effect on different biomedical attributes of potato.

Increasing levels of nitrogen significantly increased (Table 1) the height of the plant. Maximum height of the plant in 60 and 75 DAP was recorded under $200 \mathrm{~kg} \mathrm{~N} / \mathrm{ha}$, while minimum under control plots.

The supply of nitrogen is related to carbohydrate utilization. When nitrogen supply is adequate and conditions are favorable for growth, proteins are formed from the manufactured carbohydrates.

This extra protein allows the plants to grow faster. Thus, height of plant was significantly increased by increasing levels of nitrogen.

These results were also supported by Gupta (1992), Anabousi et al., (1997) and Ramirez et al., (2004).

The dose of $200 \mathrm{~kg}$ N/ha produced more number of haulms per hill than control plots. Though, the number of haulms per hill depends on the number of buds present on seed tubers, their survival with plant growth will depend on the nutrition available in the soil. 
Table.1 Response of different levels of nitrogen on growth and quality traits

\begin{tabular}{|c|c|c|c|c|c|c|c|c|c|c|c|c|c|c|c|c|}
\hline \multirow{3}{*}{ Treatments } & \multicolumn{4}{|c|}{ Emergence percentage } & \multicolumn{4}{|c|}{ Number of haulms per hill } & \multicolumn{4}{|c|}{ Plant height $(\mathrm{cm})$} & \multicolumn{4}{|c|}{ Number of leaves per plant } \\
\hline & \multicolumn{2}{|c|}{ 2014-15 } & \multicolumn{2}{|c|}{$2015-16$} & \multicolumn{2}{|l|}{ 2014-15 } & \multicolumn{2}{|c|}{$2015-16$} & \multicolumn{2}{|c|}{ 2014-15 } & \multicolumn{2}{|c|}{$2014-15$} & \multicolumn{2}{|c|}{ 2014-15 } & \multicolumn{2}{|c|}{$2014-15$} \\
\hline & $\begin{array}{c}15 \\
\text { DAP }\end{array}$ & $\begin{array}{c}\text { 30 } \\
\text { DAP }\end{array}$ & 15 DAP & $\begin{array}{c}\text { 30 } \\
\text { DAP }\end{array}$ & 60 DAP & 60 DAP & 60 DAP & 60 DAP & $\begin{array}{c}60 \\
\text { DAP }\end{array}$ & $\begin{array}{c}75 \\
\text { DAP }\end{array}$ & $\begin{array}{c}\text { 60 } \\
\text { DAP }\end{array}$ & 75 DAP & $\begin{array}{c}60 \\
\text { DAP }\end{array}$ & $\begin{array}{c}75 \\
\text { DAP }\end{array}$ & 60 DAP & 75 DAP \\
\hline $\begin{array}{ll}\text { T1: } & 0 \mathrm{~kg} \\
\text { N/ha } & \\
\end{array}$ & 61.32 & 93.35 & 56.41 & 93.00 & 186.63 & 186.63 & 186.63 & 186.63 & 47.02 & 56.90 & 48.30 & 49.75 & 30.81 & 31.31 & 31.40 & 32.10 \\
\hline $\begin{array}{l}\text { T2: } \quad 50 \\
\text { kg N/ha }\end{array}$ & 60.75 & 85.55 & 56.41 & 94.53 & 233.81 & 233.81 & 233.81 & 233.81 & 55.59 & 57.12 & 55.65 & 57.30 & 37.91 & 37.73 & 38.50 & 39.30 \\
\hline $\begin{array}{ll}\text { T3: } & 100 \\
\text { kg N/ha } & \end{array}$ & 61.30 & 93.50 & 56.56 & 94.06 & 293.22 & 293.22 & 293.22 & 293.22 & 55.95 & 67.26 & 67.70 & 69.70 & 46.01 & 47.08 & 47.40 & 48.50 \\
\hline $\begin{array}{ll}\text { T4: } & 150 \\
\text { kg N/ha } & \\
\end{array}$ & 61.75 & 78.85 & 56.72 & 94.10 & 297.60 & 297.60 & 297.60 & 297.60 & 57.46 & 72.69 & 72.55 & 74.75 & 48.28 & 49.03 & 49.50 & 50.50 \\
\hline $\begin{array}{ll}\text { T5: } & 200 \\
\text { kg N/ha } & \end{array}$ & 61.35 & 93.65 & 56.72 & 94.53 & 306.95 & 306.95 & 306.95 & 306.95 & 70.50 & 75.69 & 74.65 & 76.90 & 50.95 & 51.20 & 51.80 & 52.80 \\
\hline $\begin{array}{ll}\text { T6 } & : \\
& \\
\text { kg N/ha } & \\
\end{array}$ & 61.25 & 93.20 & 56.72 & 94.06 & 307.58 & 307.58 & 307.58 & 307.58 & 70.64 & 76.15 & 74.80 & 78.00 & 51.17 & 51.26 & 51.90 & 53.00 \\
\hline $\begin{array}{ll}\text { T7 } & : \\
& \\
\text { kg N/ha } & \\
\end{array}$ & 60.50 & 93.60 & 56.41 & 93.91 & 308.85 & 308.85 & 308.85 & 308.85 & 70.80 & 76.25 & 74.90 & 79.00 & 51.90 & 51.46 & 52.00 & 53.20 \\
\hline S.Em. \pm & 0.60 & 1.05 & 0.75 & 0.75 & 3.36 & 3.36 & 3.36 & 3.36 & 2.55 & 2.35 & 2.47 & 251 & 1.99 & 1.89 & 2.53 & 2.27 \\
\hline C.D. $(p=0.05)$ & NS & NS & NS & NS & 31.64 & 31.64 & 31.64 & 31.64 & 6.99 & 5.99 & 6.53 & 6.73 & 3.65 & 3.15 & 5.49 & 3.99 \\
\hline
\end{tabular}

\begin{tabular}{|c|c|c|c|c|c|c|c|c|c|c|c|c|c|}
\hline \multirow{3}{*}{\multicolumn{2}{|c|}{ Treatments }} & \multicolumn{4}{|c|}{ Fresh weight of plant (g) } & \multicolumn{4}{|c|}{ Dry weight of plant (g) } & \multicolumn{2}{|c|}{$\begin{array}{l}\text { Total yield of tubers } \\
\text { perplot }(\mathrm{kg})\end{array}$} & \multicolumn{2}{|c|}{$\begin{array}{c}\text { Total yield of tubers } \\
\text { per } \\
\text { hectare (q) }\end{array}$} \\
\hline & & \multicolumn{2}{|l|}{ 2014-15 } & \multicolumn{2}{|c|}{$2015-16$} & \multicolumn{2}{|l|}{ 2014-15 } & \multicolumn{2}{|c|}{$2015-16$} & \multirow[t]{2}{*}{ 2014-15 } & \multirow[t]{2}{*}{$2015-16$} & \multirow[t]{2}{*}{ 2014-15 } & \multirow[t]{2}{*}{$2015-16$} \\
\hline & & 60 DAP & 75 DAP & 60 DAP & 75 DAP & 60 DAP & 75 DAP & 60 DAP & 75 DAP & & & & \\
\hline T1: & 0 kg N/ha & 13.91 & 16.96 & 14.15 & 17.45 & 13.91 & 16.96 & 14.15 & 17.45 & 28.85 & 29.17 & 150.05 & 155.01 \\
\hline T2: & $50 \mathrm{~kg} \mathrm{~N} / \mathrm{ha}$ & 16.73 & 20.91 & 17.60 & 21.70 & 16.73 & 20.91 & 17.60 & 21.70 & 33.67 & 34.19 & 175.25 & 177.62 \\
\hline T3: & $100 \mathrm{~kg} \mathrm{~N} / \mathrm{ha}$ & 21.51 & 26.62 & 22.20 & 27.40 & 21.51 & 26.62 & 22.20 & 27.40 & 35.20 & 36.44 & 183.50 & 191.64 \\
\hline T4: & $150 \mathrm{~kg} \mathrm{~N} / \mathrm{ha}$ & 22.10 & 27.12 & 22.55 & 27.90 & 22.10 & 27.12 & 22.55 & 27.90 & 46.17 & 44.52 & 240.25 & 231.80 \\
\hline T5: & $200 \mathrm{~kg} \mathrm{~N} / \mathrm{ha}$ & 23.19 & 28.42 & 23.10 & 28.50 & 23.19 & 28.42 & 23.10 & 28.50 & 48.02 & 48.48 & 250.8 & 253.05 \\
\hline T6: & $250 \mathrm{~kg} \mathrm{~N} / \mathrm{ha}$ & 23.01 & 27.74 & 22.90 & 28.00 & 23.01 & 27.74 & 22.90 & 28.00 & 47.78 & 48.28 & 248.52 & 252.13 \\
\hline T7: & $300 \mathrm{~kg} \mathrm{~N} / \mathrm{ha}$ & 22.90 & 27.20 & 22.70 & 27.70 & 22.90 & 27.20 & 22.70 & 27.70 & 47.59 & 48.42 & 247.50 & 251.82 \\
\hline S.Er & & 3.22 & 2.99 & 2.99 & 2.89 & 3.22 & 2.99 & 2.99 & 2.89 & 1.07 & 1.89 & 0.99 & 0.907 \\
\hline C.D & $0.05)$ & 2.34 & 2.90 & 2.94 & 2.89 & 2.34 & 2.90 & 2.94 & 2.89 & 1.99 & 3.57 & 7.89 & 6.92 \\
\hline
\end{tabular}


Table 2 Physico-chemical properties of soil

\begin{tabular}{|c|c|c|c|}
\hline S.No. & $\begin{array}{l}\text { Physico-chemical } \\
\text { properties of soil }\end{array}$ & $\frac{\text { Values }}{2015-16}$ & Method employed \\
\hline A. & Mechanical analysis: & & \\
\hline 1. & Sand $(\%)$ & 53.35 & \multirow{4}{*}{ (Jackson, 1969) } \\
\hline 2. & Silt $(\%)$ & 24.95 & \\
\hline 3. & Clay (\%) & 21.70 & \\
\hline 4. & Soil texture & Sandy loam & \\
\hline \multicolumn{4}{|c|}{ B. Chemical analysis: } \\
\hline 1. & Soil reaction $(\mathrm{pH})$ & 7.80 & $\begin{array}{c}\text { 1:2.5 soil : water using glass electrode } \mathrm{pH} \text { meter } \\
\text { (Jackson, 1969) }\end{array}$ \\
\hline 2 & Organic carbon $(\%)$ & 0.27 & $\begin{array}{l}\text { Walkley and Black's rapid titration method } \\
\text { (Walkely, 1947) }\end{array}$ \\
\hline 3. & Available nitrogen $(\mathrm{kg} / \mathrm{ha})$ & 112.10 & $\begin{array}{l}\text { Alkaline potassium permangnate method } \\
\text { (Subbiah and Asija, 1956) }\end{array}$ \\
\hline 4. & $\begin{array}{l}\begin{array}{l}\text { Available phosphorus } \\
(\mathrm{kg} / \mathrm{ha})\end{array} \\
\end{array}$ & 17.20 & Olsen's method (Olsen et al., 1954) \\
\hline 5. & $\begin{array}{l}\text { Available } \\
\text { potassium(kg/ha) }\end{array}$ & 218.10 & $\begin{array}{l}\text { Flame emission spectrophotometer (Jackson, } \\
\text { 1969) }\end{array}$ \\
\hline
\end{tabular}

Availability of nitrogen with increasing rates therefore seems the main cause of increased number of haulms per hill. Positive significant effect of increased nitrogen doses on number of haulms per hill has also been reported by Gupta and Pal (1989), Singh and Singh (1994), Shirie-janagrad et al., (2009) and Udom et al., (2012).

Nitrogen application up to $200 \mathrm{~kg}$ N/ha produced taller plant which ultimately resulted in the production of more number of leaves per plant. Successive increase in nitrogen levels produce significantly more number of leaves per plant (51.207 at 75 DAP) over its lower levels. Nitrogen affects the rate and extent of protein synthesis. Therefore, it increases the plant height and number of leaves per plant. This finding was close conformity with results of Bekhit et al., (2005), Kumar et al., (2007) and Bose et al., (2008).

Yield is the (Table 2) result of the vegetative growth of the plant. Increasing nitrogen levels increased the tuber yield to a great extent. The yield increased continuously up to $200 \mathrm{~kg} \mathrm{~N} / \mathrm{ha}$. However, highest nitrogen level (300 kg N/ha) produced at par higher tuber yield with 200,250 $\mathrm{kg} / \mathrm{ha}$ nitrogen. This increase in tuber yield was due to increase in photosynthetic activity of the plant which enhance with the supply of nitrogen.

The manufactured photosynthesis help in increasing height of plants, number of leaves, number and weight of tubers per plot. Therefore, increasing nitrogen levels boosted the tuber yield tremendously. This is mainly due to more tuberization. Similar results have been reported by Castro (1988), Lakshmi et al., (2010), Dubey et al., (2012) and Jing et al., (2012).

\section{References}

Anabousi, O.A.N., Hattar, B.I. and Suwwan, M.A. 1997. Effect of rate and source of nitrogen on growth, yield and quality of potato (Solanum tuberosum. L) Under Jordan Valley conditions. Agric. Sci., 24(2): 242-259.

Anonymous. 2014. Data base, National Horticulture Board, Gurgavn, Haryana.

Bekhit, S.R., Hassan, A.H., Ramadan, M.H. and Al-Anany, A.M.A. 2005. Effect of different levels and sources of nitrogen on 
growth, yield and quality of potatoes grown under sandy soil conditions. Ann. Agric. Sci. Moshtohor, 43(1): 381.

Chaurasia, S.N.S. and Singh, K.P. 1993. Nitrogen levels and haulms cuttings effect on dry matter pationing in potato variety Kufri Lalima. J. Indian Potato Assoc., 20(3-4): 35.

Dandekar, D.N., Sharma, T.R., Sharma, R.C. and Sawarkar, S.D. 1991. Fertilizer requirements of potato cv. Kufri Badshah in Madhya Pradesh. J. Indian Potato Assoc., 18(3-4): 178-179.

Gupta, A. 1992. Response of potato to nitrogen and potassium fertilization. Indi. $J$. Agron., 37(2): 309-311.

Gupta, A. and Pal, K. 1989. Response of potato varieties to nitrogen fertilization under rainfed condition. Indian J. Agron., 34(4): 478-480.

Jackson, M.L. 1969. Soil chemical analysis advanced course (2nd edition).Published by the author, Dep. of Soil Science, Univ. of Wisconsin, Madison, WI.

Kumar, P., Pandey, S.K., Singh, B.P., Singh, S.V. and Kumar, D. 2007. Effect of nitrogen rate on growth, yield, economics and crisps quality of Indian potato processing cultivar. Potato Res., 50(2): 143-155.

Olsen, S.R., Cole, C.V., Watanabe, F.S., \& Dean, L.A. 1954. Estimation of available phosphorus in soils by extraction with sodium bicarbonate. USDA, Cire. 939, U. S. Gover. Prin. Office, Washington DC.

Ramirez, O., Cabrera, A. and Corbera, J. 2004. Nitrogen fertilization of potato (Solanum tuberosum L.) in Holguim. Optimal nitrogen doses. Cultivars Trop., 25(2): 75-80.
Satyanarayana, V. 1983. Effect of graded levels of nitrogen and potash on growth and yield of potato and their direct and residual effect on onion bulbs. Ph.D, Thesis, IARI, New Delhi.

Shiri-e-Janagrad, M., Tobeh, A., Abbasi, A., Jamaati-e-Somarin, S. and Hokmalipour, S. 2009. Vegetative growth of potato (Solanum tuberosum L.) cultivars, under the effects of different levels of nitrogen fertilizer. Res. J. Biol. Sci., 4(7): 807814.

Singh, T.P. and Singh, R.P. 1994. Effects of rates and methods of nitrogen application on bio-mass and tuber production of potato. Crop Res., 8(3): 637-639.

Subbiah, B.V. and Asija, G.L. 1956. A rapid procedure for the determination of available nitrogen in soil. Curr. Sci., 25: 259-260.

Tajner- Czopek, A., Pyllarz- Kozicka, M., Lisinska, G. and Jaryeh, M. 2005. Effect nitrogen fertilization on potato yield and quality. Sodininkystir Darzininkyste, 24(4): 231-243.

Udom, G.N., Udosen, U.U. and Owa, O. 2012. Effects of seed tuber size and Nitrogen rates on growth and yields of some potato varieties. J. Agric., Biotech. Eco., 5(1): 44-55.

Walkley, A. 1947. A critical examination of a rapid method for determination of organic carbon in soils - effect of variations in digestion conditions and of inorganic soil constituents. Soil Sci., 63: 251-257.

White, R.P. and Sanderson, J.B. 1983. Effect of planting date, nitrogen rate and plant spacing on potato growth for processing in Prince Edward Island. Am. Potato. J., 60: $115-126$.

\section{How to cite this article:}

Sriom, D.P. Mishra, Priyanka Rajbhar, Devraj Singh, Rajat Kumar Singh and Sudhir Kumar Mishra. 2017. Effect of different levels of nitrogen on growth and yield in potato (Solanum tuberosum (L.) CV. Kufri Khyati. Int.J.Curr.Microbiol.App.Sci. 6(6): 1456-1460. doi: https://doi.org/10.20546/ijcmas.2017.606.170 